\title{
PENGARUH MEREK DAN NEGARA ASAL TERHADAP SIKAP KONSUMEN DALAM MEMILIH PRODUK HANDPHONE
}

\author{
Yogi Fransiskus \\ Alumni Jurusan Manajemen Fakultas Ekonomi Universitas Negeri Medan \\ Armin Rahmansyah Nasution \\ Dosen Jurusan Manajemen Fakultas Ekonomi Universitas Negeri Medan
}

\begin{abstract}
This research aims to determine the Influence of Brand and Country of Originto Consumer Attitude when Choosing Handphone Product at Erafone Medan Fair. Population in this research is 4210 persons. and sample is 98 persons. Sampling technique that use in this research is random sampling technique. Data analysis technique used is Multiple Linear Regression. Before we do the regression, first we need to test is the relationship between variables using classical assumption test. Then t test for parcial test and F test for simultaneous test, to know whether there is influence of brand to consumer attitude in choosing handphone product, influence of country of origin to consumer attitude in choosing handphone product, and influence of brand and country of origin simultaneous to consumer attitude in choosing handphone product. Based on research that conducted, found that brand and country of origin have positive effect to consumer attitude when choosing handphone product.
\end{abstract}

Keywords: Brand, Country of Origin, Consumer Attitude

\section{PENDAHULUAN}

Di era globalisasi ini perkembangan teknologi dan informasi semakin cepat di berbagai negara termasuk Indonesia. Perkembangan teknologi yang paling dekat dengan kehidupan kita adalah alat komunikasi yang tidak lain adalah handphone atau telepon genggam. Handphone merupakan perangkat elektronik tanpa kabel yang cara kerjanya sama seperti telepon konvensional. Cara kerja handphone secara singkat yaitu mengubah suatu pesan suara dari pengirim menjadi gelombang radio yang dihubungkan melalui jaringan BTS (Base Trasceiver Station). Merek adalah nama, istilah, simbol atau rancangan, atau kombinasi dari semua hal tersebut yang dimaksud untuk mengidentifikasi barang atau jasa dari seorang atau kelompok penjual yang bertujuan untuk membedakannya dari produk pesaing. Merek berkembang sebagai respons terhadap harapan konsumen yang berubah-ubah. Yang artinya, perkembangan merek terjadi karena adanya permintaan dari konsumen yang beragam. Negara asal (Country of origin) menciptakan suatu persepsi tertentu terhadap suatu merek, persepsi tersebut bisa positif atau negatif. Country of origin dipahami sebagai efek yang muncul dalam persepsi konsumen yang dipengaruhi oleh lokasi dimana suatu produk dihasilkan. Country of origin sering dikaitkan dengan kualitas produk.

Sikap merupakan suatu mental dan syaraf sehubungan dengan 
kesiapan untuk menanggapi, diorganisasi melalui pengalaman dan memiliki pengaruh yang mengarahkan dan atau dinamis terhadap perilaku. Sikap konsumen adalah faktor penting yang akan mempengaruhi keputusan konsumen.

\section{KAJIAN PUSTAKA}

\section{Merek}

Menurut Kotler (1997) merek adalah nama, istilah, simbol atau rancangan, atau kombinasi dari semua hal tersebut yang dimaksud untuk mengidentifikasi barang atau jasa dari seorang atau kelompok penjual yang bertujuan untuk membedakannya dari produk pesaing.

Terdapat 4 indikator yang mendasari merek yaitu : merek yang terpercaya, merek yang sesuai dengan kepribadian pelanggan, merek terkenal, dan Identitas mudah dikenal. Salah satu identitas dari sebuah produk asing yang dapat dengan mudah untuk diketahui calon konsumen adalah merek. Country of origin sendiri merupakan cerminan atau bayangan mental dari sebuah produk terhadap negara tertentu.

\section{Country of Origin}

Menurut Czinkonta dan Ronkainen (2001) menyebutkan bahwa Country of Origin merupakan efek yang muncul dalam persepsi konsumen yang dipengaruhi oleh lokasi dimana produk tersebut dihasilkan.

Dasar pengukuran Country of Origin menurut Yasin, Nasser dan Osman (2007) yaitu Inovasi negara dalam berproduksi, Tingkat kemajuan teknologi asal merek, Desain produksi, Kreativitas produksi, Kualitas produksi, Prestise yang dimiliki negara asal merek, Citra negara asal merek sebagai negara maju.

\section{Sikap Konsumen}

$\begin{array}{ccr}\text { Menurut } & \text { Ujang } & \text { Sumarwan } \\ (2011: 194), & \text { Sikap } & \text { (attitude) }\end{array}$ konsumen adalah faktor penting yang akan mempengaruhi keputusan konsumen.

Pengukuran sikap konsumen yang paling sering digunakan adalah Model Multiatribut Sikap dari Fishbein (dalam Sumarwan, 2011) yaitu The Attitude Toward Object. Model ini menggambarkan bahwa sikap konsumen terhadap suatu produk atau merek ditentukan oleh tiga hal, yaitu Atribut produk (Salient Belief), kepercayaan (Belief), dan Evaluasi Atribut.

\section{METODE PENELITIAN}

Penelitian ini dilaksanakan di Erafone Mega Store Plaza Medan Fair. Lokasi ini dipilih karena berada di pusat perbelanjaan yang dikunjungi banyak orang sehingga membuat hasil kuesioner beragam yang tujuannya untuk mendapatkan hasil penelitian yang baik. Populasi adalah seluruh pengunjung Erafone Mega Store Plaza Medan Fair selama 12 bulan. Sampel diambil menggunakan rumus Taro Yamane dengan nilai toleransi $10 \%$.

\section{HASIL PENELITIAN DAN PEMBAHASAN}

Berdasarkan perhitungan SPSS, diketahui bahwa Merek dan Negara Asal secara parsial berpengaruh terhadap sikap konsumen dalam memilih handphone di Erafone Medan Fair. 
JURNAL PLANS

Penelitian Ilmu Manajemen \& Bisnis

ISSN: $1978-7057$

E-ISSN: 2527-306X

Tabel 1. Uji F

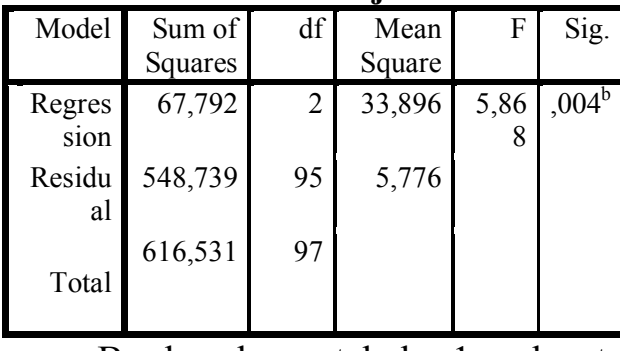

Berdasarkan tabel 1. dapat diketahui bahwa Merek dan Negara Asal sama-sama berpengaruh terhadap Sikap Konsumen.

Tabel 2. Analisis Regresi Linier

Berganda

\begin{tabular}{|c|c|c|c|c|c|}
\hline \multirow[t]{2}{*}{ Model } & \multicolumn{2}{|c|}{$\begin{array}{c}\text { Unstandardized } \\
\text { Coefficients }\end{array}$} & $\begin{array}{l}\text { Standardized } \\
\text { Coefficients }\end{array}$ & \multirow[t]{2}{*}{$\mathrm{t}$} & \multirow[t]{2}{*}{ Sig. } \\
\hline & B & $\begin{array}{l}\text { Std. } \\
\text { Error }\end{array}$ & Beta & & \\
\hline \multirow{3}{*}{$\begin{array}{l}\text { (Constant) } \\
\text { Merek } \\
\text { Negara } \\
\text { Asal }\end{array}$} & 9,758 & 4,048 & & 2,411 & ,018 \\
\hline & ,132 & ,054 & ,235 & 2,427 & ,017 \\
\hline & ,206 & 081 & ,249 & 2,563 & ,012 \\
\hline
\end{tabular}

Dari hasil SPSS diatas dapat dijelaskan sebagai berikut :

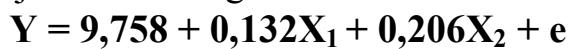

1. Konstanta sebesar 9,758 menyatakan bahwa jika tidak ada variabel $\mathrm{X}$, yaitu merek dan negara asal maka sikap konsumen memiliki nilai sebesar 9,758 dengan asumsi faktor lain konstan.

2. Koefisien X1 sebesar 0,132 menyatakan bahwa setiap terjadi peningkatan merek akan mempengaruhi sikap konsumen sebesar 0,132 dengan asumsi faktor lain konstan.

3. Koefisien X2 sebessar 0,206 menyatakan bahwa setiap terjadi peningkatan negara asal akan mempengaruhi sikap konsumen sebesar 0,206 dengan asumsi faktor lain konstan.
Tabel 3. Hasil Uji Koefisien Determinasi

Model Summary

\begin{tabular}{|c|c|c|c|c|}
\hline $\begin{array}{c}\text { Mo } \\
\text { del }\end{array}$ & $\mathrm{R}$ & $\begin{array}{c}\mathrm{R} \\
\text { Square }\end{array}$ & $\begin{array}{c}\text { Adjusted } \\
\mathrm{R} \text { Square }\end{array}$ & $\begin{array}{c}\text { Std. } \\
\text { Error of } \\
\text { the } \\
\text { Estimate }\end{array}$ \\
\hline 1 &, $332^{\mathrm{a}}$ &, 110 &, 091 & 2,403 \\
\hline
\end{tabular}

Dari tabel 3. hasil uji koefisien determinasi diketahui bahwa besarnya angka R2 adalah 0,110 , yang berarti variabel merek dan negara asal menjelaskan pengaruh terhadap variabel sikap konsumen sebesar $11 \%$ sedangkan sisanya $89 \%$ dipengaruhi oleh variabel-variabel lain seperti harga, iklan, pendapatan konsumen, sistem operasi, atau variabel lainnya.

\section{PENUTUP}

Berdasarkan hasil penelitian dan pembahasan maka dapat ditarik kesimpulan sebagai berikut :

1. Merek memiliki pengaruh positif terhadap sikap konsumen di Erafone Mega Store Plaza Medan Fair karena merek membantu konsumen mengidentifikasi produk yang memberikan manfaat bagi konsumen, serta merek juga menggambarkan seberapa tinggi kualitas suatu produk kepada calon pembeli dan pembeli. Kebanyakan konsumen memperhatikan produk mana yang memiliki banyak peminat. Karena dalam pemikiran konsumen, bila produk memiliki banyak peminat maka produk tersebut memiliki kualitas yang baik. Selain itu juga mayoritas konsumen membeli produk dengan merek yang terkenal, karena sudah teruji kualitasnya. 
2. Negara asal memiliki pengaruh positif terhadap sikap konsumen di Erafone Mega Store Plaza Medan Fair karena negara asal sering sekali dikaitkan dengan kualitas sebuah produk. Konsumen akan menggunakan negara asal suatu produk sebagai standart kualitas produk sebelum dibeli. Konsumen memperhatikan negara asal untuk memastikan produk yang akan dibelinya memiliki ketahanan yang baik. Dan juga negara asal produk mempengaruhi reputasi produk tersebut. Reputasi yang dimiliki sebuah produk, dapat menaikkan prestige dan memberikan kepuasan pribadi bagi konsumen.

3. Merek dan negara asal mempengaruhi sikap konsumen di Erafone Mega Store Plaza Medan Fair dalam memilih sebuah produk handphone secara positif. Sikap konsumen merupakan faktor penting yang akan mempengaruhi keputusan konsumen. Hal ini sangat terkait dengan konsep kepercayaan dan perilaku. Intinya yaitu sikap merupakan ungkapan perasaan konsumen tentang suatu objek apakah disukai atau tidak, dan sikap juga menggambarkan kepercayaan konsumen terhadap berbagai atribut dan manfaat dari objek tersebut. Berdasarkan kuesioner, responden dalam penelitian ini berpendapat bahwa citra produk, keseluruhan fisik produk dan testimoni orang terdekat menjadi suatu perhatian sebelum membeli sebuah produk handphone.

\section{DAFTAR PUSTAKA}

Hasan, Ali. 2013. Marketing dan Kasus-kasus Pilihan. Yogyakarta: CAPS

Jasfar, Farida. 2012. "Teori dan Aplikasi Sembilan Kunci Keberhasilan Bisnis Jasa:Sumber Daya Manusia, Inovasi, dan Kepuasan Pelanggan. Jakarta: Salemba Empat

Kotler, Philip \& Keller. 2006. Marketing Management, Manajemen Pemasaran. Jakarta: Erlangga.

Manajemen Pemasaran, Jilid 1. Edisi 12. Jakarta: INDEKS

Kuncoro, Mudrajad. 2013. Metode Riset Untuk Bisnis dan Ekonomi. Edisi 1. Jakarta: Penerbit Erlangga.

Sanusi, Anwar. 2011. Metodologi Penelitian Bisnis. Jakarta:Salemba Empat 